\title{
Ulasan Buku
}

Where is God in a Coronavirus World?, John C. Lennox, The Good Book Company, 2020. 64 halaman. Digital Book. GBP 1.59. ISBN 978-1784985691

John Lennox adalah seorang profesor emeritus di bidang matematika dari Universitas Oxford di Inggris, dosen emeritus bidang matematika dan filsafat sains di Green Templeton College serta pengajar di The Oxford Centre for Christian Apologetics. Dalam karir akademisnya, Lennox giat membela iman Kristen di dalam debat-debat publik menghadapi para ateis terkenal seperti Richard Dawkins, Christopher Hitchens dan Peter Singer.

Tulisan-tulisan dalam buku ini lahir dari perenungan Lennox terhadap situasi kegelisahan dan kebingungan yang sedang melanda dunia ini akibat pandemi virus Corona. Untuk itu, Lennox mengundang para pembacanya seumpama sedang berdialog dengannya di kafe sambil minum kopi dan bertanya: "Di manakah Allah di tengah dunia yang dilanda virus Corona?" Meskipun ditulis dalam waktu relatif singkat dan dengan jumlah halaman yang tidak banyak, buku ini memberikan wawasan yang cukup secara teologis, historis dan saintifik mengenai pandemi yang sedang terjadi saat ini. Tidak hanya itu, Lennox juga berupaya sensitif terhadap penderitaan yang sedang dihadapi pembacanya dengan menceritakan beberapa pengalaman pribadi dan keluarganya ketika menghadapi sakit penyakit.

Bagaimana Lennox menjawab pertanyaan yang diajukannya sendiri? Di manakah Allah di tengah dunia yang sedang menderita karena virus Corona? Dengan fondasi teologis yang dibangun menurut wawasan dunia Kristen, Lennox mencoba menjawab pertanyaan klasik yang sudah disampaikan oleh Epicurus pada abad ke-3. Apakah Allah ingin mencegah penderitaan tetapi tidak sanggup? Apakah Allah sanggup mencegah penderitaan tetapi tidak ingin? Atau apakah Allah tidak sanggup dan tidak ingin mencegah penderitaan? Untuk menjawab pertanyaan ini, Lennox membandingkan tiga sistem kepercayaan yang dominan-teisme, ateisme, dan panteisme-serta menunjukkan bagaimana wawasan dunia Kristen tidak hanya memberi jawaban yang masuk akal tetapi juga menawarkan penghiburan, kekuatan dan pengharapan sejati yang dapat diandalkan di tengah krisis saat ini.

Di saat kebanyakan buku-buku yang membahas masalah kejahatan dan penderitaan (problem of evil) berfokus pada kejahatan moral (moral evil), buku Lennox ini secara khusus menekankan pada kejahatan natural (natural evil) seperti bencana alam. Meskipun kejahatan moral dan natural kadangkala berhubungan, Lennox melihat pandemi virus Corona sebagai kejahatan natural karena virus yang berpindah dari hewan ke manusia tanpa disengaja atau disadari. Lennox memulai pembahasannya dengan common sense bahwa rasa sakit itu memainkan peranan yang penting dalam kehidupan manusia: (1) sebagai peringatan adanya bahaya; (2) bermanfaat dalam pertumbuhan fisik seperti para atlet; dan (3) berkontribusi dalam pembentukan karakter, seperti yang disadari oleh para orang tua ketika membiarkan anak mereka menghadapi pengalaman yang menyakitkan. Di sini Lennox mengutip Dostoyevsky yang mengatakan, "Pain and suffering 
are always inevitable for a large intelligence and a deep heart."

Sebelum menjawab pertanyaan dari judul bukunya, Lennox membereskan terlebih dahulu pandangan-pandangan yang salah terhadap penderitaan. Pertama, Lennox mengingatkan kesalahan panteisme yang mengatakan seseorang menderita karena menanggung karma (akibat dosa) dari kehidupan mereka sebelumnya sehingga melepaskan mereka dari penderitaan hanyalah memperlambat proses penyucian. Pandangan ini senada dengan teman-teman Ayub yang menuduh Ayub menderita karena hukuman Allah akibat dosa-dosanya. Karena itu, Lennox ingin mematahkan asumsi yang mengatakan bahwa Alkitab juga mengajarkan konsep penderitaan selalu dikaitkan dengan hukuman Allah atas dosa yang serius. Lennox mengutip perkataan Tuhan Yesus dalam Lukas 13:1-5 yang mengingatkan bahwa orang-orang Galilea yang dibunuh oleh Pilatus maupun 18 orang yang mati tertimpa menara dekat Siloam mengalami hal-hal buruk itu bukan karena dosa mereka lebih besar dari dosa orang-orang lain di Yerusalem. Melalui dua kasus yang melibatkan baik kejahatan moral maupun kejahatan natural itu, Tuhan Yesus menegur pandangan yang salah di antara orang-orang Yahudi pada masa itu bahwa seseorang mengalami hal-hal buruk karena mereka pendosa besar yang dihukum Allah. Memang Lennox tidak menutup mata dengan adanya penderitaan yang diakibatkan oleh dosa seseorang seperti yang dikatakan Paulus kepada jemaat Korintus (1 Kor. 11:20). Namun demikian, ia mengingatkan bahwa kita tidak mendapatkan otoritas dan wahyu khusus seperti Paulus untuk mengetahui hal tersebut. Dari semua pembahasannya itu, Lennox menarik kesimpulan bahwa semua penderitaan yang menimpa kita selama hidup di dunia ini, tidak selalu secara langsung disebabkan oleh Allah, walaupun Dia adalah Allah yang berdaulat atas segala sesuatu.
Kedua, Lennox juga mengingatkan kita untuk tidak jatuh kepada pandangan ekstrem lainnya yang membuang Allah sama sekali dari masalah penderitaan, yaitu ateisme. Menurut ateisme, semua bencana alam, termasuk wabah virus Corona, memperlihatkan bahwa Allah tidak ada, sehingga manusia hanya perlu menerima kenyataan bahwa alam semesta ini keras, tidak berperasaan, tidak berbelaskasihan dan tidak peduli apakah kita hidup atau mati. Lebih lanjut, Lennox menjelaskan bagaimana ateisme tidak dapat menolong kita dalam menghadapi masalah penderitaan. Jika tidak ada Allah maka tidak ada alasan yang rasional untuk menerima sistem moral atau etika yang menilai apa yang benar dan salah, apa yang baik dan buruk, karena semuanya itu berasal dari Allah, Sang Sumber Kebenaran. Jika ateisme diterima maka benarlah apa yang dikatakan Richard Dawkins bahwa di dalam alam semesta ini tidak ada rancangan, tidak ada tujuan, tidak ada yang baik, tidak ada yang buruk, yang ada hanyalah alam semesta yang buta dengan ketidakpedulian tanpa ampun (pitiless indifference). Dengan demikian, jika ateisme diterima maka semua penderitaan yang manusia alami, termasuk akibat wabah virus Corona, menjadi tidak masuk akal dan tidak bermakna sama sekali. Karena itu, menurut Lennox, ateisme tidak dapat menolong kita menghadapi masalah penderitaan karena menyingkirkan Allah tidak serta merta menyingkirkan penderitaan, sebaliknya malah menyingkirkan pengharapan.

Jika hanya teisme Kristen yang paling masuk akal untuk menjawab masalah natural evil, maka pertanyaan yang masih belum terjawab adalah jika Allah itu ada dan Dia mahakasih, mengapa di dunia ini ada virus Corona dan semua bencana alam lainnya? Lennox menjawab pertanyaan ini dalam tiga tahap. Pertama, Lennox mulai dengan menjelaskan kegunaan dari virus dan juga beberapa peristiwa yang dianggap bencana, seperti gempa bumi. Virus berperan di dalam 
mengendalikan pertumbuhan bakteri dan dengan demikian telah menjaga fungsi ekosistem serta siklus daur ulang nutrien. Pergerakan lempeng tektonik (yang menyebabkan gempa bumi) ternyata bermanfaat di dalam menjaga keseimbangan antara daratan dan lautan, sebagai pengatur suhu global yang mendaur ulang unsur-unsur kimia yang krusial di dalam menjaga keseimbangan kadar karbon dioksida, serta menjaga medan magnet yang berfungsi melindungi bumi dari sinar kosmik yang berbahaya bagi kehidupan. Kendati pun demikian, dapatkah Allah membuat sebuah dunia yang hanya ada virus baik tetapi tidak ada virus patogen? Dapatkah Allah menciptakan makhluk hidup yang tidak pernah berbuat jahat?

Lennox menjawab pertanyaan di atas dengan poin kedua, yaitu bahwa Allah menciptakan manusia sebagai makhluk bermoral dengan kapasitas kehendak bebas untuk memilih percaya dan mengasihi Allah dan sesama dengan tulus, atau memilih untuk tidak taat kepada Allah dan melakukan yang jahat. Pada mulanya Allah menciptakan bumi dan segala makhluk di dalamnya dengan sangat baik dan harmonis karena berjalan di dalam ketaatan kepada Allah. Semua penyimpangan dan hal-hal buruk yang terjadi kemudian adalah akibat dari ketidaktaatan manusia, yang memilih menentukan sendiri jalan hidupnya di luar rencana dan kehendak Allah. Karena manusia menolak Allah maka dosa masuk ke dalam dunia dan merusak seluruh tatanan ciptaan Allah. Alam ciptaan tidak lagi bersahabat dengan manusia, melainkan ikut menjadi rusak dan bersifat memusuhi manusia. Peradaban manusia pun selanjutnya diisi dengan keserakahan, korupsi, kekerasan, serta sikap dan perbuatan destruktif lainnya. Lennox tidak hanya menjelaskan fakta yang disampaikan Alkitab namun juga memberikan dukungan dari beberapa filsuf ateis yang menyatakan kecacatan natur manusia. Maka Lennox menyimpulkan bahwa kita dihadapkan pada fakta dan realitas yang bercampur antara dunia yang baik dan indah dengan dunia yang penuh virus patogen serta kejahatan lainnya yang menghancurkan kehidupan manusia. Di tengah realitas yang demikian, adakah Allah yang baik yang dapat kita percayai dan andalkan untuk hidup dan masa depan kita?

Lennox menjawabnya dengan poin ketiga, yaitu Allah yang membuktikan kasih-Nya di dalam karya penebusan Yesus Kristus di atas kayu salib. Kematian Kristus adalah bukti bahwa Allah tidak tinggal diam terhadap penderitaan manusia, melainkan yang merengkuh dan ikut mengalami rasa sakit itu. Karena itu, bagi seorang percaya di dalam Kristus, meskipun masalah penderitaan dan sakit penyakit belum terpecahkan, ia tetap dapat mempercayai dan mengasihi Allah yang sudah terlebih dahulu mengasihinya. Kematian Kristus juga mengajak kita untuk melihat kejahatan bukan pada pihak lain tetapi kepada diri kita sendiri sebagai orang berdosa yang membutuhkan penebusan. Namun kematian Kristus bukanlah akhir dari segalanya. Kebangkitan-Nya yang mengalahkan kematian justru memberikan pengharapan bahwa ada keadilan sejati yang paling puncak yang akan ditegakkanNya pada saat kedatangan-Nya yang kedua kali. Karena itu, Lennox mengajak pembacanya untuk melihat kepada dua mahkota. Virus Corona (yang artinya mahkota dalam bahasa Latin) mengingatkan kita akan kerapuhan manusia sebagai makhluk yang fana. Namun pengharapan yang sejati hanya ada pada mahkota yang lain, yaitu mahkota duri di atas kepala Kristus.

Lennox mengakhiri bukunya dengan memberikan beberapa nasihat bagaimana orang Kristen dapat berespons terhadap pandemi ini. Pertama, kita dapat menjaga hati dan pikiran dengan perspektif kekekalan seperti di atas yang memberikan pengharapan sehingga tidak terus-menerus dikuasai ketakutan melainkan dapat tetap menjalankan aktivitas kehidupan sehari-hari. Kedua, kita dipanggil untuk mengasihi dan melayani 
orang dengan cara memperhatikan anjuran medis dalam menjaga sanitasi dan kesehatan diri sendiri serta orang-orang lain di sekitar yang berisiko tertular. Kita juga dapat terlibat membantu menyediakan kebutuhan hidup sehari-hari dari mereka yang sakit atau membutuhkan pertolongan. Lennox memberikan contoh nyata dari sejarah bagaimana gereja mula-mula mulai dari abad ke-2 hingga zaman Reformasi berkontribusi nyata di tengah situasi pandemi dengan menolong siapa saja yang sakit dan membutuhkan bantuan melalui peran mereka masing-masing.
Buku ini mungkin akan selesai dibaca dengan sekali duduk, namun topik yang dibahas akan terus-menerus mengajak kita merenung dan takjub akan siapa Allah dan apa yang telah dikerjakan-Nya bagi kita, serta mendorong kita untuk proaktif bertindak menyatakan kasih-Nya di tengah dunia yang sedang menderita ini. Buku ini diterjemahkan oleh Literatur Perkantas Jawa Timur dan dapat diunduh di tautan http://dimana. literaturperkantas.com.

$$
\begin{array}{r}
\text { Sandra Wisantoso } \\
\text { Sekolah Tinggi Teologi SAAT, Malang } \\
\text { sandra.wisantoso@seabs.ac.id } \\
\text { https://doi.org/10.36421/veritas.v19i1.365 }
\end{array}
$$

The New Testament in Its World: An Introduction to the History, Literature, and Theology of the First Christians, N.T. Wright dan Michael F. Bird, London: SPCK dan Grand Rapids: Zondervan, 2019. 987 halaman. Hardcover. USD 32.99. ISBN 978-0310499305

Buku ini adalah karya yang terbaru dalam genrenya. ${ }^{1}$ Namun, buku ini bukan yang terbaru dalam pendekatannya-sejarah, sastra dan teologi, sebab Mark Allan Powell menulis pengantar Perjanjian Baru (PB) dengan metode yang sama. ${ }^{2}$ Kendati demikian, buku ini unik. Pertama, sebagai buku sederhana atau contoh agar mudah dipahami (reader atau sampler) mengenai pemikiran N.T. Wright. Hal ini tidak terlepas dari usulan Bird supaya Wright menulis buku pengantar PB, setelah Wright menulis banyak buku mengenai PB (hal. 25-26). Kedua, buku ini bertujuan menjadi buku yang handal dan ramah. Handal karena ditulis untuk memahami kekristenan mula-mula dan ramah karena dilengkapi buku kerja, pembelajaran online, bahan video dan audio,

${ }^{1}$ Buku pengantar Perjanjian Baru terakhir dengan pendekatan teologi-biblika ala Reformed dalam bahasa Ing-gris adalah yang ditulis oleh Michael J. Kruger et al., ed., A Biblical-Theological Introduction to the New Testament: The Gospel Realized (Wheaton: Crossway, 2016).

${ }^{2}$ Mark Allan Powell, Introducing the New Testament: A Historical, Literary, and Theological Survey. Grand Rapids: Baker, 2009. serta kurikulum berbasis jemaat (hal. 26). Ketiga, buku ini berusaha menghindar dari beberapa problem umum yang biasa disajikan dalam buku pengantar PB. Bila dipandang perlu, hal mengenai itu telah ditulis dengan teliti, singkat dan mudah dicerna. Ketika menjelaskan masing-masing kitab dalam PB, buku ini memberikan pengantar singkat, diskusi persoalan penting dan kontekstual, garis besar kitab, komentar singkat, dan tips untuk aplikasi dan penyelidikan lebih lanjut (hal. 26).

Buku ini terdiri dari sembilan bagian yang berisi 37 pasal sepanjang 987 halaman: (1) bagaimana membaca PB (hermeneutika, sejarah, sastra, dan teologi); (2) sejarah orang Yahudi sejak era Persia hingga Roma dan Yesus dalam konteks orang Yahudi, gereja mula-mula dan Yunani-Romawi; (3) identitas Yesus dan kematian-Nya; (4) kebangkitan Yesus dan Anak Allah; (5) identitas Paulus, teologi, dan karya-karyanya; (6) Injil; (7) kekristenan mula-mula dan misi Allah dalam perspektif surat-surat am dan Wahyu; (8) bagaimana terjadinya PB; dan (9) 
bagaimana $\mathrm{PB}$ bisa up to date untuk masa kini. Seperti terlihat dalam kesembilan bagian ini, isinya memenuhi janji penulis. Selain itu, penelitian kontemporer mengenai PB didiskusikan di beberapa tempat, misalnya dalam paragraf singkat-padat tentang recent trends in contemporary Pauline scholarship (hal. 413).

Terlalu banyak kontribusi buku ini yang bisa disebutkan, di antaranya adalah membantu pembaca masa kini berpikir sebagaimana pembaca PB pada abad pertama. Misalnya, setelah membahas konteks Yahudi (hal. 108141) dan konteks filsafat Yunani-Romawi mengenai Yesus dan gereja mula-mula (hal. 142-160), buku ini memberi contoh bagaimana kedua konteks itu memengaruhi konsep Kristen dalam injil Yohanes. Logos sebagai gelar Yesus bukan saja berakar dari pandangan mesianis Yahudi dalam Mazmur 33:6, Yesaya 55:11 dan lain sebagainya, tetapi juga meminjam ide-yang semula berasal dari abad ke-6 SM yaitu Heraklitus dan kemudian dipakai oleh filsuf Stoa-untuk menggambarkan prinsip rasio yang olehnya alam semesta diciptakan dan eksis. Logos menjadi ide yang dipersonifikasi, olehnya Allah yang tidak tampak berinteraksi dengan dunia ini. Ide ini dikembangkan Filo dari Aleksandria (abad ke-2 SM) dan kemudian oleh Yustinus Martir (abad ke-2 M., hal. 161). Intinya, orang-orang Kristen memakai filsafat kuno untuk menjelaskan kepercayaan mereka tentang Allah (hal. 161).

Kontribusi lain ialah proposal Yesus sebagai Israel baru, yang selengkapnya dapat dibaca berikut ini:

Jesus took his own story seriously-so seriously that, having recommended to his followers a particular way of being Israel-forthe-sake-of-the-world, he made that way thematic for his own sense of vocation, his own belief about how the kingdom would come through his own work and especially in his death. He would turn the other cheek; he would go the second mile; he would take up the cross. He would be the light of the world, the salt of the earth. $\mathbf{H e}$ would be Israel for the sake of the world. He would be the means of the kingdom's coming, both in that he would embody in himself the renewed Israel and in that he would defeat evil once and for all. But the way in which he would defeat evil would be the way consistent with the deeply subversive nature of his own kingdom-announcement. He would defeat evil by letting it do its worst to him" (hal. 259, penekanan oleh pengulas).

Kontribusi ini jelas adalah ide brilian dari buku ini, yang tidak terlepas dari pemikiran Wright dalam bukunya Jesus and the Victory of $\mathrm{God}^{3}$ dan juga menjadi subtema ketika menulis paragraf di atas. Namun pemikiran ini menjadi kontroversial sebab Wright dituduh sedang merendahkan karya penebusan (atonement) Yesus. Kematian Yesus tidak dipandang sebagai penebusan yang menggantikan manusia. Kritikan ini tampak benar saat buku ini mengatakan tentang "dibenarkan oleh iman" dalam surat Galatia,

... although Paul argue ferociously about justification by faith, the key question he is dealing with is, 'Who are God's people and how do you know?' He is, in other words, talking about identity. What matters is being a Messiah-person; that is the key to forgiveness, status, and hope. God has launched his new creation in which the old differences, necessary for the time, cease to matter (hal. 414, penekanan dari buku).

Mengenai surat Roma, Wright berkata,

Paul knows that the Romans have received a true gospel tradition; he wants to fill this

${ }^{3}$ N.T. Wright, Jesus and the Victory of God, Christian Origins and the Question of God, vol. 2 (Minneapolis: Fortres, 1997). 
out with his own rich gospel insights, emphasizing that gentiles are justified by faith without adopting the Jewish way of life (hal. 524, penekanan oleh peninjau),

lalu ia melanjutkan,

The same lord is lord of all; Jesus died and rose to be the lord of all; all who call on the name of the lord will be saved. Justification by faith means fellowship by the same faith. To walk the 'Roman road' (as some have called the gospel presentation in this letter) is not only to discover one's sins forgiven by the God of utter love and mercy, but also to learn that this lavish forgiveness was always intended to draw people of all sorts into a single family. Multiethnic churches should be the norm, not the exception" (526, penekanan oleh peninjau)

Buku ini cenderung memaknai "dibenarkan oleh iman" bukan dalam matriks soteriologis ala reformasi, seperti Luther dan Calvin, namun lebih sosiologis dan eklesiologis. Kecurigaan terhadap hal ini tidak mengejutkan sebab Wright adalah defender dari apa yang disebut sebagai New Perspective on Paul (NPP), sementara Bird agak malu-malu menceburkan dirinya ke arah itu. Namun dalam buku ini tampak jelas tema-tema NPP bertebaran, misalnya: monotheism-electioneschatology (370-377, lihat indeks buku); Jewishness (lihat entri Jewish Diaspora, Jewish mysticism, Jewish sectarianism, Jews dalam indeks buku). Sementara sebagian orang mencibir pandangan NPP yang tampak dalam buku ini, perlu diingat bahwa hal ini tidak terlepas dari perdebatan mengenai the quest of the historical Jesus yang bermula dari Albert Schweitzer dan kawan-kawan (First Quest), Rudolf Bultmann dan Karl Barth (Second Quest), Ben F. Meyer dan E.P. Sanders (Third Quest) di mana studi mengenai Yesus ditempatkan dalam konteks Yahudi (hal. 176-186). Wright berjasa membalikkan pendulum perdebatan mengenai hal ini agar Yesus tidak terusir dari keyahudianNya sendiri.

Bahasa Inggris yang sederhana dan ringan, keterkaitan bahasan dengan konteks masa kini, banyaknya gambar dan chart, ringkasan dan lain sebagainya, bukan saja menjadi kelebihan buku ini namun membuatnya enak dibaca, sehingga yang sukar menjadi mudah dipahami. Saya mendapati (setelah memakai banyak buku pengantar PB untuk mengajar beberapa tahun terakhir ini), The New Testament In Its World adalah buku terbaik dalam genrenya. Keseimbangan memahami dan mengevaluasi keberbedaan atas persoalan yang ditemukan di sekitar PB telah ditunjukkan Wright dan Bird. Hal ini layak diapresiasi sebab begitulah standar yang harus dimiliki seorang akademikus. Terlepas dari beberapa kelemahan, seperti yang diutarakan di atas dan mungkin masih ada lebih banyak lagi, mahasiswa teologi dan pembaca umum layak mempertimbangkan buku ini jika bermaksud mengetahui PB dengan baik dan seimbang.

Andreas Hauw

Sekolah Tinggi Teologi SAAT, Malang andreas.hauw@seabs.ac.id https://doi.org/10.36421/veritas.v19i1.362 